Biol. Proced. Online 2004;6(1): 129-136.

doi: $10.1251 /$ bpo81

\title{
Flow cytometry based techniques to study testicular acidophilic granulocytes from the protandrous fish gilthead seabream (Sparus aurata L.)
}

\author{
Elena Chaves-Pozo', Victoriano Mulero', José Meseguer and Alfonsa García Ayala* \\ 'Department of Cell Biology, Faculty of Biology, University of Murcia, Campus Universitario de Espinardo. \\ 30100 Murcia, Spain.
}

*To whom correspondence should be addressed: Alfonsa García Ayala, Department of Cell Biology, Faculty of Biology, University of Murcia, Campus Universitario de Espinardo. 30100 Murcia, Spain. Phone: +34-968364968; Fax: +34-968-363963; Email: agayala@um.es

Submitted: March 17, 2004; Revised: June 11, 2004; Accepted: June 11, 2004; Published: June 29, 2004.

Indexing terms: Testis; Flow cytometry; Phagocytosis.

Abbreviations: BW, body weight; BSA, bovine serum albumin; SR-2, steroid-free synthetic serum; PBS, phosphate-buffered saline; FCS, fetal calf serum; FITC, fluorescein isothiocyanate; FSC, forward scatter; SSC, side scatter; TSB, trypticase soy broth; FC, flow cytometry; ANOVA, one-way analysis of variance; mAb, monoclonal antibody; IL-1 $\beta$, interleukin- $1 \beta$.

\begin{abstract}
The gilthead seabream is a protandrous seasonal breeding teleost that is an excellent model for studying the testicular regression process which occurs in both seasonal testicular involution and sex reversion. Little is known about the cell types and the molecular mechanisms involved in such processes, mainly because of the lack of appropriate methods for testis dissociation, and testicular cell isolation, culture and functional characterization. We have previously reported that gilthead seabream acidophilic granulocytes infiltrate the testis at post-spawning stage, settle close to the spermatogonia and accumulate intracellular interleukin-1 $\beta$. In this paper, we report several flow cytometry based assays which allow to establish the role played by gilthead seabream testicular acidophilic granulocytes and permits their quantification.
\end{abstract}

\section{INTRODUCTION}

Spermatogenesis is a complex process in which primary spermatogonia divide and differentiate into spermatozoa. In fish, spermatogenesis appears to proceed in a similar fashion to that observed in mammalian vertebrates. However, the seminiferous tubules of mammalian vertebrates contain several successive generations of germ cells, all of which depend on the same Sertoli cell (1), while the fish testes are characterized by a cystic structure in which all the germ cells belonging to the same cyst are at the same spermatogenetic stage and progress synchronously surrounded by a cohort of Sertoli cells (2). This structure means that the fish testis is an excellent system for studying the 
regulation of spermatogenesis. Recently, it has been suggested that testicular macrophages play an important role in the mammalian testicular function (3). However, in fish, the cells present in the testicular connective tissue are not well characterized, and neither is their role in the regulation of spermatogenesis or in the morphological changes that the fish testis undergoes throughout the reproductive cycle. The gilthead seabream (Sparus aurata L.) is a protandrous seasonal breeding teleost that permits the seasonal regression of the testis and sex reversion to be studied. To date, very few cell dissociation, culture and functional assays have been succesfully established to study spermatogenesis in fish $(4,5)$. In this study, we have developed several techniques that, when used together with a specific monoclonal antibody ( $\mathrm{mAb}$ ), allow us to characterise and quantify the functional activities of gilthead seabream testicular acidophilic granulocytes throughout the reproductive cycle.

\section{MATERIALS AND METHODS}

\section{Fish}

Healthy specimens of mature male gilthead seabream, with body weight (BW) of $100 \mathrm{~g}$ were obtained in November, 2002, from Predomar, S.L. (Carboneras, Spain). The fish were kept at the Spanish Oceanografic Institute (Mazarrón, Murcia), in $14 \mathrm{~m}^{3}$ running-seawater aquaria (dissolved oxygen $6 \mathrm{ppm}$, flow rate $20 \%$ aquaria volume/hour) at natural temperature and photoperiod, and fed twice with a commercial pellet diet (Trouvit, Burgos, Spain). The gonads were removed from the specimens and processed as described below. The animal treatment procedure applied was under considerations of the Bioethical Committee of the University of Murcia.

\section{Testicular cell suspension}

The testes were dissociated using a modified protocol from Loir and Sourdaine (6). The organ was removed and placed on sbtL15 medium [L-15 medium (Gibco) adjusted to gilthead seabream serum osmolarity $(353.33$ mosmol) with $0.35 \% \mathrm{NaCl}$ (Sigma), supplemented with $20 \mathrm{mM}$ HEPES (Gibco), $3 \mathrm{mM}$ $\mathrm{NaHCO}_{3}$ (Sigma), $112 \mathrm{mg} / 1 \mathrm{~L}(+)$-lactic acid (Sigma), $1 \mathrm{mg} / 1$ glutathione (Sigma), 0.5\% gelatin (Sigma), $2 \mathrm{nM} \mathrm{CuCl}_{2}$ (Sigma), 6

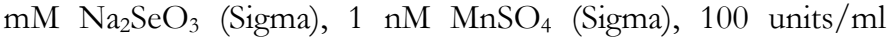
penicillin and $100 \mathrm{mg} / \mathrm{ml}$ streptomycin (P/S, Biochrom)]. The testes were cut and incubated for 5 hours in dissociation medium [Hank's medium (Hank's balanced salt solution without calcium supplemented with $20 \mathrm{mM}$ HEPES, $5 \mathrm{mM} \mathrm{NaHCO}$, $5 \mathrm{mg} / 1$ glutathione, $2 \mathrm{nM} \mathrm{CuCl}, 6 \mathrm{mM} \mathrm{Na} \mathrm{SeO}_{3}, 1 \mathrm{nM} \mathrm{MnSO} 4,5.5$ $\mathrm{mg} / 1 \alpha$-tocopherol acetate (vitamin E, Sigma), $112 \mathrm{mg} / \mathrm{l} \mathrm{L}(+)-$ lactic acid, $110 \mathrm{mg} / \mathrm{l}$ pyruvate (Gibco), essential amino acids (Gibco), non essential amino acids (Gibco), vitamin mixture (Gibco), $0.35 \% \mathrm{NaCl}$ (Sigma), $30 \mathrm{nM} \mathrm{L-ascorbic} \mathrm{acid} \mathrm{(vitamin} \mathrm{C,}$ Sigma), $2 \mathrm{mM}$ glutamine (Gibco), 2\% steroid-free synthetic serum (SR-2) (Serum Replacement 2, Sigma)) with $1.1 \mathrm{~g} / 1$ colagenase (Sigma)]. One hour after the start of incubation 20 $\mu \mathrm{g} / \mathrm{ml}$ of DNAse I (Sigma) was added.

After dissociation, the testis pieces were incubated overnight in sbt-L15 medium supplemented with $1 \%$ bovine serum albumin
(BSA, Sigma), $3 \mathrm{mg} / 1$ all trans-retinol acetate (vitamin A, Sigma), $1 \mathrm{mg} / 1$ vitamin E, $2 \mathrm{mM}$ glutamine and $2 \%$ SR-2. Afterwards, the testis pieces were forced through a $100 \mu \mathrm{m}$ nylon mesh and the cell suspension obtained was filtered through a $65 \mu \mathrm{m}$ nylon mesh, washed, counted using a Newbauer chamber and adjusted to $5 \times 10^{5}$ cells $/ \mathrm{ml}$ in sbt-L15 medium.

\section{Immunofluorescence}

Aliquots of $5 \times 10^{5}$ testicular cells were washed in flow cytometry (FC) buffer [phosphate-buffered saline (PBS) containing 2\% fetal calf serum (FCS) and $0.05 \%$ sodium azide] and incubated for 30 minutes on ice with $100 \mu \mathrm{l}$ of a $\mathrm{mAb}$ specific to gilthead seabream acidophilic granulocytes (G7) (7), at the optimal dilution of 1:100 in FC buffer. After being washed, cell suspensions were incubated for 30 minutes on ice with $50 \mu \mathrm{l}$ of fluorescein isothiocyanate (FITC)-labelled anti-mouse $\mathrm{F}(\mathrm{ab})_{2}$ fragments of goat antibody (Sigma) at the optimal dilution of 1:100 in FC buffer. Cells were then washed twice and the findings were depicted in the form of two-parameter forward scatter (FSC) and side scatter (SSC) dot plots and green fluorescence (FL1) histograms by using a fluorescence-activated cell sorter (Becton Dickinson). The specificity of staining was checked by using a mAb isotype standard. Each $\mathrm{G} 7$ staining was carried out in duplicate.

\section{Labelling of Vibrio anguillarum with FITC}

The fish pathogenic bacterium Vibrio anguillarum (strain R-82, serotype 01) was grown overnight in a trypticase soy broth (TSB) with $1 \% \mathrm{NaCl}$ and $50 \mu \mathrm{g} / \mathrm{ml}$ FITC (Sigma) at $25^{\circ} \mathrm{C}$ in a lightprotected environment. After labelling, free FITC was removed by washing 3 times in PBS and the bacteria were inactivated by heating for 20 minutes at $60^{\circ} \mathrm{C}$, adjusted to $10^{9}$ bacteria $/ \mathrm{ml}$ and then stored at $-80^{\circ} \mathrm{C}$.

\section{Phagocytosis assay}

The phagocytosis of $V$. anguillarum by gilthead seabream testicular cells was studied by FC using a modified protocol from Esteban et al. (8) and by electron microscopy. Briefly, aliquots of $5 \times 10^{5}$ testicular cells in sbt-L15 medium were left untreated or treated with $500 \mu \mathrm{g} / \mathrm{ml}$ of colchicine (Sigma) for 2 hours at $25^{\circ} \mathrm{C}$. Afterwards, testicular cells were mixed with $10^{7}$ FITC-labelled bacteria, centrifuged at $300 \mathrm{~g}$ for 5 minutes, resuspended and incubated for 60 minutes at $25^{\circ} \mathrm{C}$ in a light-protected environment. After the incubation period, the phagocytosis was stopped with ice-cold PBS and the fluorescence of non-ingested bacteria was quenched with a solution of $0.4 \%$ trypan blue in PBS. The number of green fluorescent cells (phagocytic cells) was analysed by FC, as described above. Aliquots of cells challenged with $V$. anguillarum for periods ranging from 30 to 90 minutes were also processed for electron microscopy (see below) using $4 \%$ glutaraldehyde in $0.1 \mathrm{M}$ cacodylate buffer ( $\mathrm{pH} 7.2)$ as fixative. Each phagocytosis assay was carried out in duplicate. 


\section{Viability assay}

Aliquots of testicular cell suspensions were diluted in $200 \mu \mathrm{l}$ PBS containing $40 \mu \mathrm{g} / \mathrm{ml}$ propidium iodide. The number of red fluorescent cells (dead cells) from triplicate samples was analysed by FC.

\section{Light and electron microscopy}

Small pieces of testis were fixed in Bouin solution, embedded in Paraplast Plus (Sherwood Medical) and sectioned at $5 \mu \mathrm{m}$. After dewaxing and rehydratation, the sections were stained with haematoxylin-eosin and examined with a Axiolab (Zeiss) light microscope.

For electron microscopy, samples were fixed in $4 \%$ glutaraldehyde in $0.1 \mathrm{M}$ cacodylate buffer ( $\mathrm{pH}$ 7.2) for 2 hours at $4^{\circ} \mathrm{C}$, then postfixed in $1 \%$ osmium tetroxide in $0.1 \mathrm{M}$ cacodylate buffer ( $\mathrm{pH}$ 7.2) for 1 hour at $4^{\circ} \mathrm{C}$ and embedded in Epon. Ultrathin sections were obtained with a Reichert-Jung ultramicrotome, contrasted with uranyl acetate and lead citrate and examined with a Zeiss EM 10C electron microscope.

\section{Statistical analysis}

All the analysis were made using cells from at least four different fish. Data were analysed by one-way analysis of variance (ANOVA) and unpaired Student's t-test to determine difference between groups. A quantitative study of the FC results was made by using the statistical option of the Lysis Software Package (Becton Dickinson).

\section{RESULTS AND DISCUSSION}

In this study, conventional FC based techniques were used to clarify the cell population involved in testis regression and germ cell removal. In the protandrous fish gilthead seabream, the tight and highly specialised intercellular unions established in the testis may complicate testis dissociation, for which reason enzymatic and mechanical dissociation methods were used to obtain a testicular cell suspension. After the enzymatic treatment, the cells must be allowed to recover overnight in a highly enriched medium. Medium osmolarity was adjusted to that of gilthead seabream serum by adding $0.35 \% \mathrm{NaCl}$. Using this technique, cell viability was around $80 \%$, as assayed by propidium iodide staining.

We analysed the testes of gilthead seabream during the resting stage, a reproductive stage in which spermatogonia is the main cell type in the germinal compartment of the testis (Fig. 1). At this stage, spermatogenetic activity is limited to spermatogonia recrudescence after testicular involution and the resorption of the remaining germ cells during the post-spawning stage. The testicular cells are heterogeneous in size and complexity, and it is difficult to distinguish populations from FSC and SSC parameters. Moreover, the testis is formed of changeable germ cell populations, which increase in number and decrease in size as the spermatogenesis proceeds. Therefore, we only divided the testicular cell suspension into two regions (R1 and R2) according to cell granularity (SSC) (Fig. 2A).

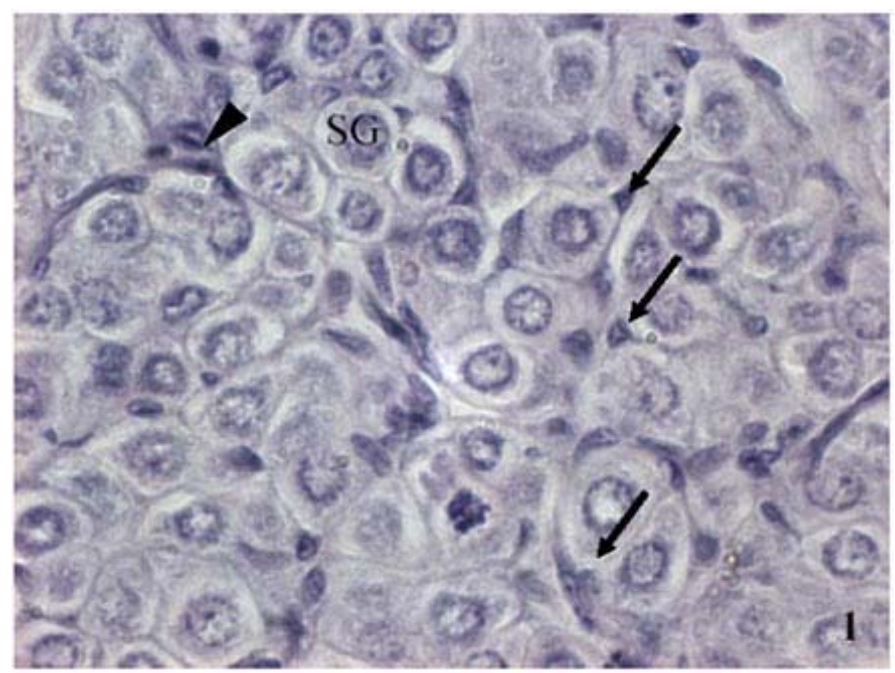

Fig. 1: General view of gilthead seabream testis at the resting stage stained with haematoxylin-eosin. Note that the main cell type is the spermatogonia (SG) and that spermatogonia are surrounded by Sertoli cells (arrows). Arrow head, interstitial tissue. x100.

In contrast to germinal compartment cells, the testicular connective cells have not been well characterised in fish. More specifically, the relative amount of the different leucocyte types and their function in the fish testis are unknown. However some microscopical observations have pointed to the appearance of macrophages, acidophilic granulocytes and lymphocytes in the testicular connective tissue of some teleosts in different stages of the reproductive cycle, mainly during post-spawning (9-14). We have previously reported that gilthead seabream acidophilic granulocytes infiltrate the testis at post-spawning, settle close to the spermatogonia and accumulate intracellular interleukin-1 $\beta$ (IL-1 $\beta$ ) (15). However, the abundance and the precise role of this cell type is unknown. Therefore, we applied several FC based techniques to characterise and quantify testicular acidophilic granulocytes, using a specific mAb (G7) previously produced in our lab (7). Taking into account that the G7 antibody recognises an acidophilic granulocyte-specific membrane bound protein, icecold incubation and inclusion of sodium azide are extremely important in order to avoid antigen uptake after antibody recognition. The G7 antibody only recognised $1 \pm 0.5 \%$ of the cells in the testicular suspension of gilthead seabream at the studied stage, but interestingly, the acidophilic granulocytes $\left(G 7^{+}\right.$ cells) belong exclusively to the $\mathrm{R} 2$ region where they represented around $30 \%$ of the cells (Figs. $2 \mathrm{~B}$ and C). 

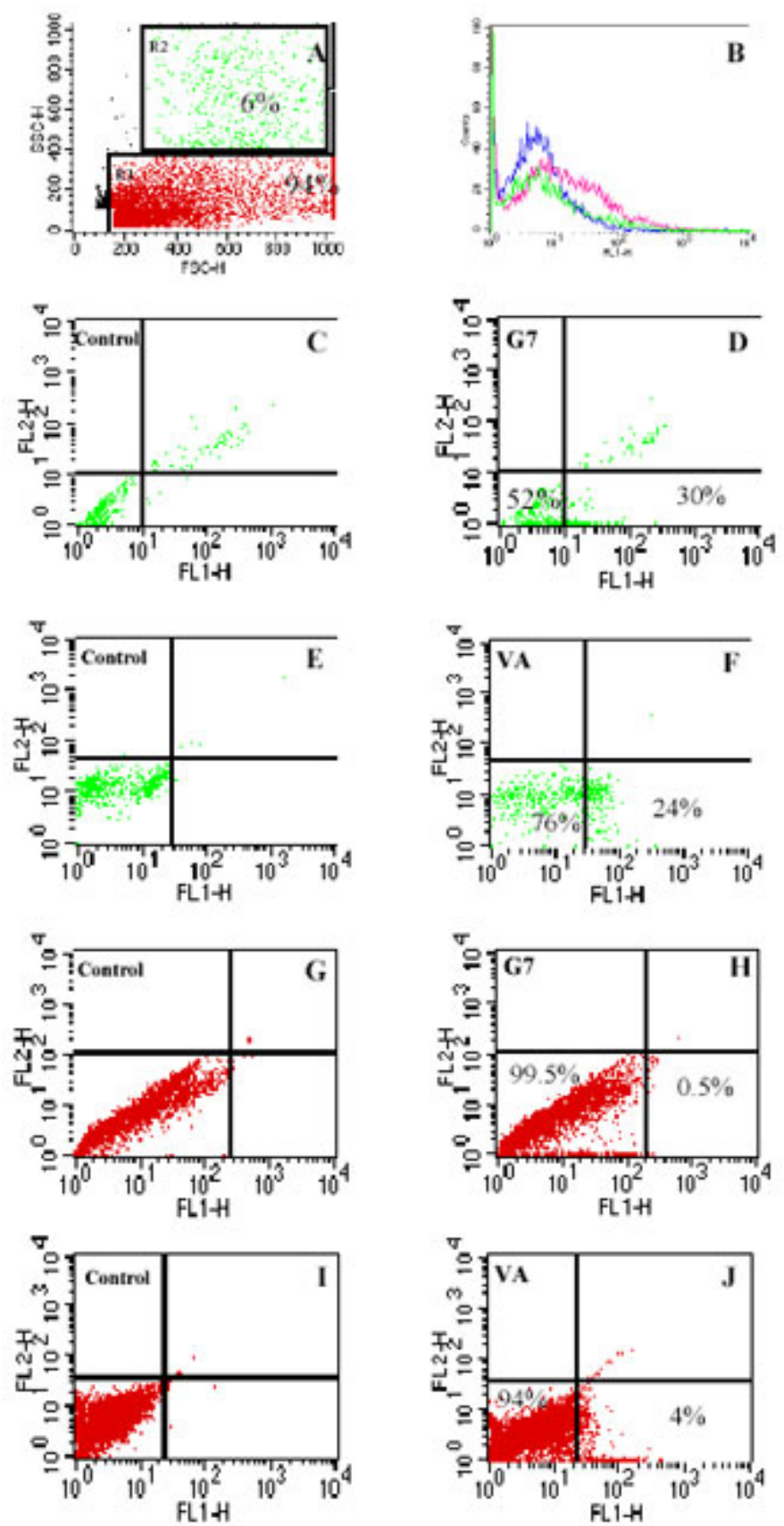

Fig. 2: Flow cytometry analysis of gilthead seabream testicular cell suspension. (A) Representative dot blot of FSC (size) vs SSC (granularity). (B) Representative FL1 (green fluorescence) histograms of testicular cells incubated in the absence (pink histogram) or presence (blue histogram) of $500 \mu \mathrm{g} / \mathrm{ml}$ colchicine for 2 hours and then challenged with FITC-labelled $V$. anguillarum for 1 hour. Non-challenged cells (green histogram) were also shown for comparison. (C-J) Representative dot blots of FL1 (green fluorescence) vs FL2 (red fluorescence) of cells present in region R1 (G-J) and region R2 (C-F) stained with G7 (D, H), challenged with FITC-labelled bacteria (VA) (F, J) or negative controls (C, E, G, I). Note that both R1 and R2 regions had a phagocytic cell population $(\mathrm{F}, \mathrm{J})$ and that only cells belonging to the $\mathrm{R} 2$ region were stained with G7 (D).

We were able to quantify the percentage of phagocytic cells present in the testicular cell suspensions by FC. For the data to be reliable, the assay has to be conducted on ice after the incubation time to avoid bacterium digestion and fluorescence quenching by phagosomal acidification. Cells treated with colchicine, a drug that blocks the polymerisation of microtubules, was used as appropriate negative control. Cells pretreated with colchicine and then challenged with FITC-labelled bacteria showed a similar fluorescence to non-challenged cells, indicating that trypan blue succesfully quenched the fluorescence of noningested bacteria (Fig. 2D). Applying this technique, $10 \pm 3 \%$ of testicular cells showed phagocytic activity against $V$. anguillarum. Notably, phagocytic cells are present in both R1 and R2 regions, where they represent around $4 \%$ and $24 \%$, respectively, in each region (Figs. 2E and F). These data suggest the existence of two cell populations (non granulated and granulated) with phagocytic activity in the testis of the gilthead seabream. Sertoli cells are considered to be the main cell population with phagocytic capacity involved in the elimination of germ cells in the testis 13 , 16-18). Our data suggest that, if it is the case, not all Sertoli cells show phagocytic activity against $V$. anguillarum during the resting stage of the reproductive cycle, since the percentage of phagocytic cells obtained was very low compared with the estimated number of Sertoli cells in the gilthead seabream testis during the resting stage (Fig. 1). The similar percentage of both acidophilic granulocyte and granulated phagocytic cells present in testicular cell suspension, together with the fact that gilthead seabream head kidney acidophilic granulocytes show high phagocytic activity against $V$. anguillarum (7), promted us to use electron microscopy to identify the cell types showing phagocytic activity against this bacterium in the gilthead seabream testis. Strikingly, cells with ultrastructural features of gilthead seabream acidophilic granulocytes $(7,19,20)$ were never observed to contain ingested bacteria (Fig. 3A), suggesting that the cells of R2 region with phagocytic activity were not acidophilic granulocytes. However, there is a testicular cell population that was able to ingest the bacterium (Fig. 3B), indicating that the testis is not depleted in defense against bacterial infection. Unfortunately, the lack of specific markers against gilthead seabream macrophages and testicular somatic cells means that it was, up to day, impossible to determine the nature of the cell type showing phagocytic activity against $V$. anguillarum in the testis during the resting stage. Our data do not exclude, however, a phagocytic role for testicular acidophilic granulocytes during other reproductive stages since the fish testis is a changeable organ with tightly regulated cell activity.

To conclude, our data support that fish testicular cells may be cultured and analysed by FC (21), although several modifications of the currently available methods are needed, depending on the fish salinity adaptation and the complexity of the testis of each species studied. To our knowledge, this is the first time that testicular acidophilic granulocytes have been characterised and quantified in a testicular cell suspension, by using FC based techniques. Moreover, we show that it is possible to use FC to study testicular cell phagocytic activity, a function that may be involved in the abrupt morphological changes that occur in this organ during a very tight timing schedule in the reproductive cycle. 


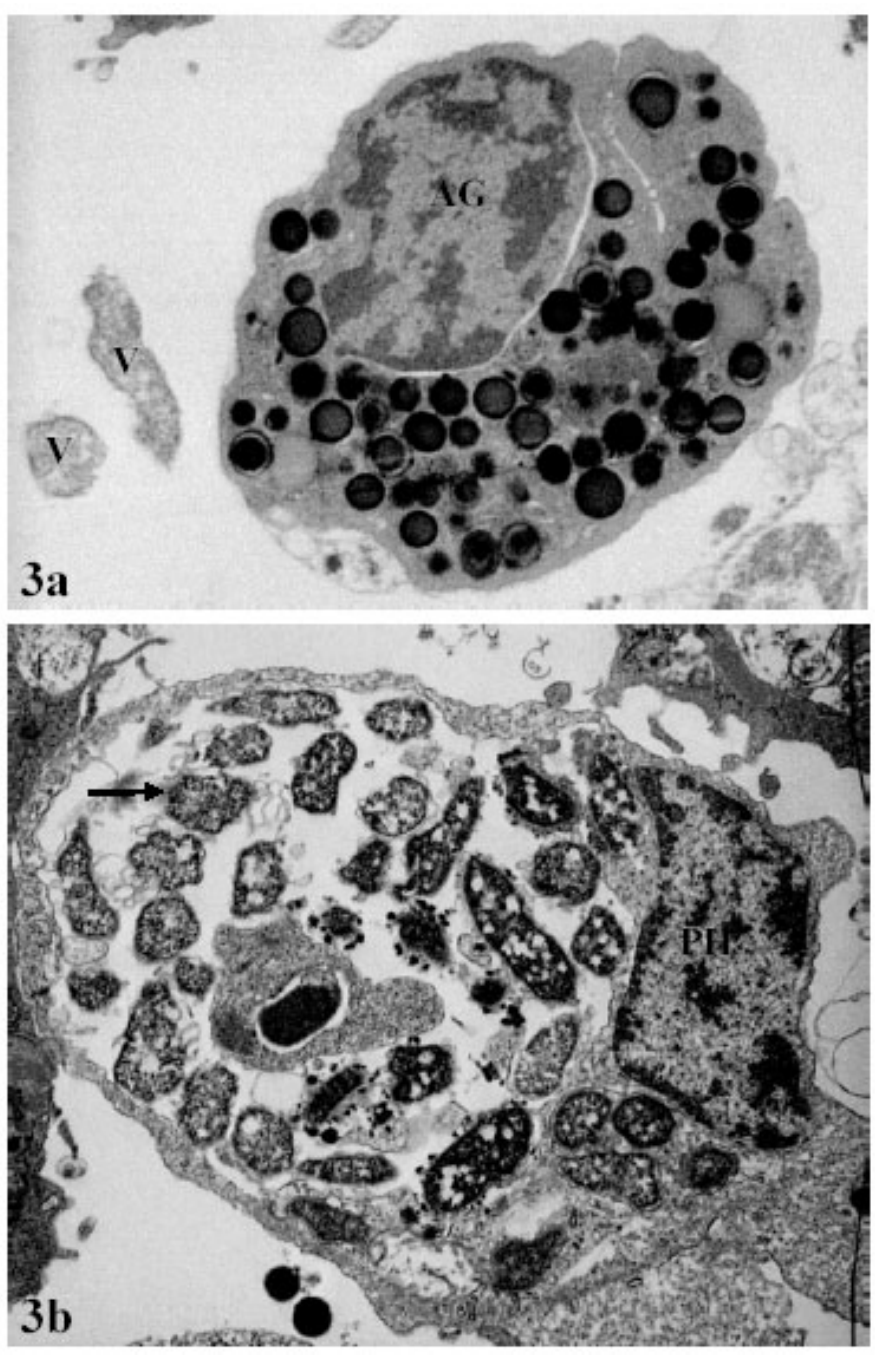

Fig. 3: Transmission electron microscopic pictures of an acidophilic granulocyte (AG) with numerous cytoplasmic granules which does not phagocytose the bacterium $(\mathrm{V})(\mathrm{a})$ and a phagocytic cell $(\mathrm{PH})$ with a large phagosome containing numerous bacteria (arrow) (b) from a testicular cell suspension incubated with Vibrio anguillarum for 90 minutes. (a) $\times 4000$, (b) x5000.

\section{ACKNOWLEDGMENTS}

We thank the "Servicio de Apoyo a las Ciencias Experimentales" S.A.C.E. of the University of Murcia for their assistance with cell culture and electron microscopy, the Spanish Oceanographic Institute of Mazarron for keeping the fish, and Drs. A. E. Toranzo and J. L. Barja (University of Santiago de Compostela) for the $V$. anguillarum. This work was supported by Fundación Séneca, Coordination Centre for Research (grant PI51/00782/FS/01) and Spanish Ministry of Education, Culture and Sports (fellowship to E. Chaves-Pozo).

\section{REFERENCES}

1. Hess RA. Spermatogenesis, overview. In: Knobil E, Neil JD, editors. Encyclopedia of Reproduction volumen 4. New York: Academic Press; 1999. p.539-545.
2. Miura T. Spermatogenetic cycle in fish. In: Knobil E, Neil JD, editors. Encyclopedia of Reproduction volumen 4. New York: Academic Press; 1999. p. 571-578.

3. Hales DB. Testicular macrophage modulation of Leydig cell steroidogenesis. J Reprod Immunol 2002; 57:3-18.

4. Loir M. In vitro approach to the control of spermatogonia proliferation in the trout. Mol Cell Endocrinol 1994; 102:141150.

5. Miura T, Yamauchi K, Takahashi H, Nagahama Y. Hormonal induction of all stages of spermatogenesis in vitro in the male Japanese eel (Anguilla japonica). Proc Natl Acad Sci USA 1991; 88:5774-5778.

6. Loir M, Sourdaine P. Testes cells: isolation and culture. In: Hochachka, Mommsen editors. Biochemistry and Molecular Biology of Fishes volumen 3. Elsevier Science Press; 1994. p. 249-272.

7. Sepulcre MP, Pelegrín P, Mulero V, Meseguer J. Characterisation of gilthead seabream acidophilic granulocytes by a monoclonal antibody unequivocally points to their involvement in fish phagocytic response. Cell Tissue Res 2002; 308:97-102.

8. Esteban MA, Mulero V, Muñoz J, Meseguer J. Methodological aspects of assesing phagocytosis of Vibrio anguillarum by leucocytes of gilthead seabream (Sparus aurata L.) by flow cytometry and electron microscopy. Cell Tissue Res 1998; 293:133-141.

9. Stanley H, Chieffi G, Botte V. Histological and histochemical observations on the testis of Gobius paganellus. Z Zellforsch 1965; 65:350-362.

10. Shrestha TK, Khanna SS. Histology and seasonal changes in the testes of a hill-stream fish Schizothorax plagiostomus. Z Mikrosk. Anat Forsch 1976; 90:749-761.

11. Shrestha TK, Khanna SS. Seasonal changes in the testes of a hill stream teleost, Garra gotyla (Gray). Acta Anat 1978; 100:210-220.

12. Micale V, Perdichizzi F, Santangel G. The gonadal cycle of captive white bream, Diplodus sargus (L.). J Fish Biol 1986; 31:435-440.

13. Besseau L, Faliex E. Resorption of unemitted gametes in Lithognathus mormyrus (Sparidae, Teleostei): a possible synergic action of somatic and immune cells. Cell Tissue Res 1994; 276:123-132

14. Bruslé-Sicard S, Fourcault B. Recognition of sex-inverting protandric Sparus aurata: ultrastructural aspect. J Fish Biol 1997; 50:1094-1103.

15. Chaves-Pozo E, Pelegrín P, Mulero V, Meseguer J, García Ayala A. A role for acidophilic granulocytes in the testis of the gilthead seabream (Sparus aurata L., Teleostei). J Endocrinol 2003; 179:165-174.

16. Van den Hurk R, Peute J, Vermeij JA. Morphological and enzyme cytochemical aspects of the testis and vas deferens of the rainbow trout, Salmo gairdneri. Cell Tissue Res 1978; 186:309-325.

17. Billard R, Takashima F. Resorption of spermatozoa in the sperm duct of rainbow trout during the post-spawning period. Bull Japan Soc Sci Fish 1983; 49:387-392.

18. Scott AP, Sumpter JP. Seasonal variations in testicular germ cell stages and in plasma concentrations of sex steroids in 
male rainbow trout (Salmo gairdneri) maturing at 2 years old. Gen Comp Endocrinol 1989; 73:46-58.

19. Meseguer J, Esteban MA, Muñoz J, López-Ruiz A. Ultrastructure of the peritoneal exudate cells of seawater teleosts, seabream (Sparus aurata) and sea bass (Dicentrarchus labrax). Cell Tissue Res 1993; 273:301-307.

20. López-Ruiz A, Esteban MA, Meseguer J. Blood cells of the gilthead seabream (Sparus aurata L.). Light and electron microscopic studies. Anat Rec 1992; 234:161-171.

21. Miura T, Ando N, Miura C, Yamauchi K. Comparative studies between in vivo and in vitro spermatogenesis of Japanese eel (Anguilla japonica). Zoolog Sci 2002; 19:321-329. 


\section{Isolation of testicular cells}

\section{PROTOCOLS}

1. Remove the testis and place in sbt-L15 medium.

2. Cut the testis into aproximately $1 \mathrm{~mm}^{2}$ pieces and place $1 \mathrm{gr}$ testis in $6 \mathrm{ml}$ dissociation medium [Hank's medium containing $1.1 \mathrm{~g} / 1$ colagenase (Sigma) previously sterilized by u.v. irradiation]. Incubate the testicular pieces for 1 hour at $25^{\circ} \mathrm{C}$ with slow shaking.

3. Add $20 \mu \mathrm{g} / \mathrm{ml}$ DNAse I (Sigma) previously sterilized by u.v. irradiation and dissolved in a small volume of Hank's medium. Incubate for 4 hours at $25^{\circ} \mathrm{C}$ with slow shaking.

4. After incubation, remove the dissociation medium, and incubate the testis pieces with sbt-L15 medium supplemented with $1 \%$ bovine serum albumin (BSA, Sigma), $3 \mathrm{mg} / 1$ all trans-retinol acetate (vitamin A, Sigma), $1 \mathrm{mg} / 1 \mathrm{vitamin} \mathrm{E,} 2 \mathrm{mM}$ glutamine and $2 \%$ SR-2 overnight at $25^{\circ} \mathrm{C}$ with slow shaking.

5. Force the testis pieces through a nylon mesh of $100 \mu \mathrm{m}$ size using sbt-L15 medium, rinse cell suspension by centrifuging for 5 minutes at $300 \mathrm{~g}$ and filter through a nylon mesh of $65 \mu \mathrm{m}$ size. Wash the cell suspension twice with sbt-L15 medium by centrifuging for 5 minutes at $300 \mathrm{~g}$, count using a Newbauer chamber and adjust to $5 \times 10^{6} \mathrm{cells} / \mathrm{ml}$ in sbt-L15 medium.

\section{Immunofluorescence}

1. Wash aliquots of $5 \times 10^{5}$ testicular cells in ice-cold FC buffer by centrifuging for 5 minutes at $300 \mathrm{~g}$.

2. Incubate the cells with $100 \mu$ l of $\mathrm{G} 7 \mathrm{mAb}$ diluted 1:100 in FC buffer for 30 minutes on ice.

3. Wash the cells twice in ice-cold FC buffer by centrifuging for 5 minutes at $4^{\circ} \mathrm{C}$ and $300 \mathrm{~g}$.

4. Add $50 \mu \mathrm{l}$ with a fluorescein isothiocyanate (FITC)-labelled anti-mouse F(ab') 2 fragments of goat antibody (Sigma) diluted 1:100 on ice-cold FC buffer and incubate for 30 minutes on ice in a light-protected environment.

5. Wash the cells twice in ice-cold FC buffer by centrifuging for 5 minutes at $4^{\circ} \mathrm{C}$ and $300 \mathrm{~g}$ in a light-protected environment.

6. Resuspend the cells in $200 \mu$ lice-cold FC buffer and analyse by FC.

\section{Phagocytosis assay}

\section{Labelling of Vibrio anguillarum (strain $R-82$, serotype 01 )}

a. Grow the bacteria in $20 \mathrm{ml}$ trypticase soy broth (TSB, Pronadisa) with $1 \% \mathrm{NaCl}$ and $50 \mu \mathrm{g} / \mathrm{ml} \mathrm{FITC} \mathrm{(Sigma)} \mathrm{overnight} \mathrm{at} 25^{\circ} \mathrm{C}$ in a light-protected environment.

b. Wash three times in phosphate buffer saline (PBS) by centrifuging for 10 minutes at $1000 \mathrm{~g}$.

c. Inactivate the bacteria heating at $60^{\circ} \mathrm{C}$ for 20 minutes.

d. Wash once in PBS by centrifuging for 10 minutes at $1000 \mathrm{~g}$.

e. Measure OD at $600 \mathrm{~nm}$ and adjust to $10^{9} \mathrm{cfu} / \mathrm{ml}\left(0.5 \mathrm{OD}\right.$ units $\left.-10^{8} \mathrm{cfu} / \mathrm{ml}\right)$.

f. Aliquot and store at $-80^{\circ} \mathrm{C}$.

\section{Flow cytometry (FC) analysis}

a. Incubate aliquots of $5 \times 10^{5}$ testicular cells with or without $500 \mu \mathrm{g} / \mathrm{ml}$ colchicine (Sigma) during 2 hours at $25^{\circ} \mathrm{C}$.

b. Mix the aliquots with $10^{7}$ FITC-labelled bacteria and centrifuge 5 minutes at room temperature and $300 \mathrm{~g}$.

c. Resuspend by pipetting and incubate 60 minutes at $25^{\circ} \mathrm{C}$ in a light-protected environment.

d. Add $500 \mu \mathrm{l}$ of ice-cold PBS and place the samples on ice in order to stop the phagocytosis.

e. $\quad$ Add $50 \mu$ l of ice-cold trypan blue $(0.4 \%$ in PBS).

f. Mix gently, acquire and analyse by FC.

\section{Electron microscopy analysis}

a. Challenge $10^{7}$ testicular cells with $2 \times 10^{8}$ heat-inactived bacteria and centrifuge 5 minutes at room temperature and $300 \mathrm{~g}$.

b. Resuspend by pipetting and incubate from 30 to 90 minutes at $25^{\circ} \mathrm{C}$.

c. Add $500 \mu \mathrm{l}$ of ice-cold PBS and place the samples on ice in order to stop the phagocytosis.

d. Centrifuge 5 minutes at $300 \mathrm{~g}$.

e. Resuspend in $4 \%$ glutaraldehyde in $0.1 \mathrm{M}$ cacodylate buffer $(\mathrm{pH} 7.2)$ during 1 hour at $4^{\circ} \mathrm{C}$.

f. Process for conventional electron microscopy. 


\section{Viability assay}

1. Dilute aliquots of $5 \times 10^{5}$ testicular cells in $200 \mu \mathrm{l}$ PBS containing $40 \mu \mathrm{g} / \mathrm{ml}$ propidium iodide.

2. Analyse by FC.

\section{Buffers and media}

\section{1. sbt-L15 medium}

\begin{tabular}{ll}
\hline Reagent & Final concentration \\
\hline $\mathrm{L}-15$ powder (Gibco) & $12.18 \mathrm{~g} / \mathrm{l}$ \\
$\mathrm{NaCl}$ (Sigma) & $35 \mathrm{~g} / \mathrm{l}$ \\
$\mathrm{HEPES}$ (Gibco) & $4.76 \mathrm{~g} / 1$ \\
$\mathrm{NaHCO}$ (Sigma) & $248 \mathrm{mg} / 1$ \\
$\mathrm{~L}(+$ )-lactic acid (Sigma) & $112 \mathrm{mg} / 1$ \\
Glutathione (Sigma) & $1 \mathrm{mg} / \mathrm{l}$ \\
Gelatine (Sigma) & $0.5 \mathrm{~g} / \mathrm{ml}$ \\
$\mathrm{CuCl}_{2}$ (Sigma) & $0.25 \mu \mathrm{g} / 1$ \\
$\mathrm{Na}_{2} \mathrm{SeO}_{3}$ (Sigma) & $5 \mu \mathrm{g} / \mathrm{l}$ \\
$\mathrm{MnSO}_{4}$ (Sigma) & $0.15 \mu \mathrm{g} / 1$ \\
$\mathrm{Penicillin}_{\text {SStreptomycin }(\mathrm{P} / \mathrm{S}, \text { Biochrom) }}$ & $100 \mathrm{units} / \mathrm{ml} / 100 \mathrm{mg} / \mathrm{ml}$ \\
\hline
\end{tabular}

Measure and adjust the $\mathrm{pH}$ to 7.4 .

\section{Hank's medium}

\begin{tabular}{ll}
\hline Reagent & Final concentration \\
\hline Hank's powder (Sigma) & $12.18 \mathrm{~g} / 1$ \\
$\mathrm{HEPES}$ & $4.76 \mathrm{~g} / 1$ \\
$\mathrm{NaHCO}_{3}$ & $413 \mathrm{mg} / 1$ \\
$\mathrm{Glutathione}_{\mathrm{CuCl}_{2}}$ & $5 \mathrm{mg} / 1$ \\
$\mathrm{Na}_{2} \mathrm{SeO}_{3}$ & $0.25 \mu \mathrm{g} / 1$ \\
$\mathrm{MnSO}_{4}$ & $5 \mu \mathrm{g} / 1$ \\
$\alpha$-tocopherol acetate (Sigma) & $0.15 \mu \mathrm{g} / 1$ \\
$\mathrm{~L}(+)-$ lactic acid & $5.5 \mathrm{mg} / 1$ \\
Pyruvate (Gibco) & $112 \mathrm{mg} / 1$ \\
Essential aminoacids 50x (Gibco) & $110 \mathrm{mg} / 1$ \\
Non-essential aminoacids 100x (Gibco) & $1 \mathrm{x}$ \\
Vitamin mixture 100x (Gibco) & $1 \mathrm{x}$ \\
NaCl & $1 \mathrm{x}$ \\
L-ascorbic acid (Sigma) & $3.5 \mathrm{~g} / 1$ \\
Glutamine (Gibco) & $30 \mathrm{nM}$ \\
Serum Replacement 2 (Sigma) & $2 \mathrm{mM}$ \\
\hline
\end{tabular}

Measure and adjust the $\mathrm{pH}$ to 7.4 .

\section{Phosphate buffer saline (PBS)}

- $\quad$ Mix $2.67 \mathrm{~g} \mathrm{Na}_{2} \mathrm{HPO}_{4}, 0.828 \mathrm{~g} \mathrm{NaH}_{2} \mathrm{PO}_{4}$ and $17.55 \mathrm{~g} \mathrm{NaCl}$ in 21 distilled water and adjust the $\mathrm{pH}$ to 7.4.

\section{FC buffer}

- $\quad$ PBS containing $2 \%$ fetal calf serum (FCS) and $0.05 \%$ sodium azide.

\section{Cacodylate buffer $0.1 \mathrm{M}$}

- $\quad$ Dilute $21.4 \mathrm{~g}$ sodium cacodilate in 11 of distilled water and adjust the $\mathrm{pH}$ to 7.2.

\section{Bouin solution}

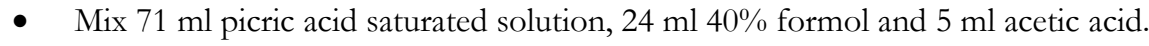

